\title{
Bacterial Contamination of Mortadella in Three Palestinian Factories
}

\author{
N. H. El-Nakhal \\ Ex. Microbiology Department Faculty of Pharmacy, Al-Azhar University, Gaza, Palestine
}

\begin{abstract}
An investigation on certain bacterial contaminants of Mortadella produced by three Palestinian factories has been carried out. One sample (2units) was taken monthly (June/1999-may/2000) from each of three local factories (A, B\&C). The lowest viable bacterial count recorded was $1 \times 10^{3} \mathrm{CFU} / \mathrm{g}$. in sample $\mathrm{No}$. $\mathrm{C} 1$, while the highest count was $3 \times 10^{7} \mathrm{CFU} / \mathrm{g}$. in sample No. B5. Some bacterial strains were isolated during the course of this study by using specific isolation media. They were identified and distributed as: Salmonella spp. $\quad(40 \%)(S$. typhi, 6 strains, S. arizonae, 4 strains and $S$. infantis, 2 strains), Eschirichia spp. (50\%) (E. coli, 8 strains and $E$. coli 0157:H7, 7 strains), anaerobic Streptococcus parvulus (3.3\%) (One strain) and Clostridum spp. (6.7\%) (Cl. baratii, one strain and $\mathrm{Cl}$. botulinum, 2 strains). Three samples (A1, C3 and B10) were mix contaminated; two pathogenic bacterial strains were isolated from each. All investigated samples were negative for Yersinia spp. and Campylobacter spp. The scientific and medical importance was discussed.
\end{abstract}

Meat and meat products' microbial contamination comes from different sources during bleeding, handling and processing. The main sources of microbial contaminations are the animal hide, hoofs, hair and the intestinal tract contents (Ayers, 1955). The nature of meat composition is a good medium for bacterial growth. Strict aerobes, facultative anaerobes as well as strict anaerobes are generally found meat suitable for their growth. Meat products are prepared from various ingredients, any or all of which may contribute to the presence of microorganisms in the final product (James, 1978). Off odor was noted in some Mortadella in markets. Different food borne pathogens were isolated from meat and meat products. These include wide variety of microorganisms: Bacillus cereus, Clostridium spp., Escherichia spp., Salmonella spp., Shigella spp., Staphylococcus aureus, Streptococcus spp., Listeria spp., Yersinia spp., Campylobacter spp. and other genera and species (Hali and Angelotti, 1965). S. aureus count in ground beef ranged from $10^{2}$ to $4.5 \times 10^{3} \mathrm{CFU} / \mathrm{g}$ (Stilps, 1981). Hali and Angelotti, (1965) reported that anaerobic bacteria are able to grow within the meat and meat products causing putrefaction. Putrefaction of foods is often caused by proteolyic species such as $\mathrm{Cl}$. putrefacions, $\mathrm{Cl}$. lentoputrescens and $\mathrm{Cl}$. baratii (Hali and Angelotti, 1965). Cl. botulinum, causes food intoxication while other Clostridium members were reported as food poisoning microorganisms (Sheroff et al., 1964 and Shapiro, 1998).

Salmonella spp. includes enteric pathogens, which may grow in food and cause food infections (Scott, 1957 and Mossel 1962). Salmonella food poisoning and salmonellosis may occur due to food contamination with any serotype of Salmonella spp. such as $S$. typhi, $S$. newport, S. panama, S. sandiego , S. montevideo (Angelotti et al., 1959). Salmonellosis may also cause death (Angelotti et al., 1959 and Stephen, et al., 1985). Acid resistance and tolerance are important virulence determinants that contribute to the survival and pathogenicity of infections by food borne pathogens such as enterohaemorrahgic E. coli (Robert and Sharon 1999). Infections with acid resistant E. coli; O157:H7 pose a clear danger to public health as this strain is extremely virulent and found in the intestinal tract and feces of both animals and man. It could be transmitted from animal to animal, animal to man through contaminated food and man-to-man through close contact. It can survive in both refrigeration and freezing temperatures but destroyed by thorough cooking (Botton et al., 1998; Abdul-Raouf et. al., 1993, 1994 and Abdul-Raouf and Ammar, 1995).

Campylobacter jejuni is an important cause of food born infections and it can cause at least as many cases of human gastroenteritis as does Salmonella spp. (Stern, 1982). It is associated mostly with chicken products. (Hazelger, 1995 
and Abdel-Hady 2000). Yersinia enterocolitica has also been isolated from wide variety of sources in the environment including food (Joklik and Amos 1980 and Lewis and Chottopadhyuo, 1986).

The aim of this study is to investigate the presence of possible bacterial contaminants in Mortadella products.

\section{Material and methods}

Samples collection. A total of 36 Mortadella samples were collected. One sample (2 units) was taken monthly from each of three local factories $(\mathrm{A}, \mathrm{B}, \mathrm{C})$ through the period from June/1999 to May/2000. The samples were sent immediately to the laboratory in a small icebox and each sample was labeled with a serial code number.

Samples preparation. Samples were prepared according to the technique recommended by the International Commissions on Microbiological Specification of Food (ICMSF-1978) as follows: a) Samples emulsion No.1: Twenty five grams of each sample were transferred aseptically with $225 \mathrm{ml}$. of sterile $1 \%$ buffered peptone water to special sterile stomacher bag (standard polyethylene). The sample was homogenized by using electrical stomacher for 2 minutes to provide $10^{-1}$ diluted homogenate, higher up to $10^{-5}$ dilution were prepared. B) Samples emulsion No. 2: The same as the above technique was done but $225 \mathrm{ml}$ sterile selenite broth medium was used then incubated aerobically for $24 \mathrm{hrs}$ at $37^{\circ} \mathrm{C}$. c) Samples emulsion No. 3: The same as the above technique was used; $225 \mathrm{ml}$. sterile thioglycolate broth medium; which was incubated anaerobically for $48 \mathrm{hrs}$ at $37^{\circ} \mathrm{C}$. d) Samples emulsion No. 4: Ten grams of the sample were transferred with $90 \mathrm{ml}$ of M-YE enrichment broth of Yersinia enterocolitica into a stomacher sac, homogenized and incubated at $25^{\circ} \mathrm{C}$ for 72 hours.

Media. Plate count agar (Difico, USA), Salmonella selective medium (xylose lysine deoxycholate Agar, Oxoid, England), blood thioglycolate agar (for anaerobic bacteria), Yersinia selective agar with Yersinia antibiotic supplement (Oxoid, England); Compylobactor selective agar (Oxoid, England) as well as sorbitol MacConkey agar (Oxoid, England) were used.

\section{Staining characteristics.}

Both Gram's stain (Hucker, 1927) and spore stain (Conklin, 1934) were used.

Anaerobiosis test. Anaerobiosis was detected by using a semisolid thioglycollate medium according to NIH, 1946.

Motility test. Stabbing inoculation of semisolid medium in slants was used according to Kun and Abood 1949.

Physiological and Biochemical characteristics. They were performed as described in Table 1 .

Salmonella Serotyping. It was done by using polyvalent and monovalent Salmonella $O$ antisera (Pasteur Co.). This assay was done as described by Edward and Ewing, 1972. E. coli O157:H7 suspected microorganism was confirmed by $E$. coli $\mathrm{O} 157: \mathrm{H} 7$ anti-serum (Difco, USA). Production of agglutination indicated positive reaction and confirms identity. Identification keys. Major international identification keys as well some recommended references were consulted for the identification of bacterial isolates under investigation: (Patricia el al., 1966 and Krieg et al., 1986).

Table (1): Physiological and Biochemical tests used.

\begin{tabular}{ll}
\hline \multicolumn{1}{c}{ Test } & \multicolumn{1}{c}{ Reference } \\
\hline Sensitivity to potassium cyanide (KCN) & Moller, 1954 \\
Oxidase test & Kovacs, 1956 \\
Catalase test & Ewing and Davis, 1970 \\
Nitrate reduction test & American Society for Microbiology, 1981 \\
Gelatinase production & Chapman, 1952 \\
Lecithinase test & Sinell and Baumgar, 1967 \\
Indol production test & Ewing and Davis, 1970 \\
Malonate splitting and phenylalanine deamination test & Shaw and Clark, 1955 \\
MR and VP test & Barritt, 1936 and Leifson, 1952 \\
Starch hydrolysis & Sutter et al, 1975 \\
Lipase test & Sutter et al., 1975 \\
Arginin and ornithine break down & Moller, 1955 \\
Utilization of inorganic cabon sources as a sole source of carbon & Stainer and Palleroni, 1966 \\
Acid production from some carbohydrates & Board and Holding, 1960 \\
\hline
\end{tabular}


Identification of isolated bacterial strains. A total number of 52 bacterial strains have been isolated under anaerobic conditions. According to anaerobiosis test results, it was found that only 3 isolates are strictly anaerobic (Table 3 ) while the remaining 49 bacterial isolates were facultative anaerobic (19 strains Gram positive cocci and 30 strains were Gram positive spore forming bacilli). A total of 12 Salmonella strains have been isolated on XLD medium and 15 bacterial isolates isolated on sorbitol MacConkey agar (Table 4). The selected 30 bacterial isolates (Table 3,4$)$ were differentiated on the basis of Gram-reaction, anaerobiosis, sporulation and cell morphology into three groups : Group 1, Gram negative facultative anaerobic bacilli to coccobacilli; Group 2, Gram-positive anaerobic non spore forming cocci and Group 3, Grampositive anaerobic spore forming bacilli. All samples under investigation were negative for both Yersinia spp. and Campylobacter spp. In group1, twenty-seven Gram-negative facultative anaerobic bacilli to coccobacilli were suggestive to belong to two genera; Salmonella and Echerichia.

Twelve Salmonella strains were isolated on XLD medium and were characterized as nonspore forming Gram-negative facultative anaerobic bacilli to coccobacilli that ferment glucose and mannose but not ferment lactose, reduce nitrate and oxidase negative. According to these characteristics, they were identified as

Table (2): Aerobic plate count (APC).

\begin{tabular}{cccccc}
\hline Sample No. & CFU/g & Sample No. & CFU/g & Sample No. & CFU/g \\
\hline A1 & $2 \times 10^{6}$ & A5 & $1.7 \times 10^{4}$ & A9 & $2 \times 10^{6}$ \\
B1 & $4 \times 10^{4}$ & B5 & $3 \times 10^{7}$ & B9 & $1.5 \times 10^{5}$ \\
C1 & $1 \times 10^{3}$ & C5 & $2.6 \times 10^{6}$ & C9 & $2.9 \times 10^{5}$ \\
A2 & $6 \times 10^{3}$ & A6 & $3.5 \times 10^{3}$ & A10 & $5.5 \times 10^{4}$ \\
B2 & $5 \times 10^{4}$ & B6 & $7 \times 10^{3}$ & B10 & $7 \times 10^{3}$ \\
C2 & $4.5 \times 10^{3}$ & C6 & $5.8 \times 10^{3}$ & C10 & $3.5 \times 10^{3}$ \\
A3 & $9 \times 10^{6}$ & A7 & $6 \times 10^{4}$ & A11 & $2.5 \times 10^{3}$ \\
B3 & $6 \times 10^{6}$ & B7 & $2.8 \times 10^{4}$ & B11 & $6 \times 10^{4}$ \\
C3 & $5 \times 10^{5}$ & C7 & $4 \times 10^{4}$ & C11 & $3 \times 10^{5}$ \\
A4 & $8 \times 10^{5}$ & A 8 & $1.8 \times 10^{6}$ & A12 & $6 \times 10^{5}$ \\
B4 & $2 \times 10^{5}$ & B8 & $3 \times 10^{6}$ & B12 & $2.8 \times 10^{4}$ \\
C4 & $3.2 \times 10^{6}$ & C8 & $2.1 \times 10^{4}$ & C12 & $1.8 \times 10^{5}$ \\
\hline
\end{tabular}

members of genus Salmonella. Polyvalent and monovalent Salmonella $\mathrm{O}$ antisera were used to classify these isolates into its species: $S$. typhi (1, $5,10,20,24,27) S$. arizonae $(3,9,14,17)$, and S. infantis $(6,19)$.

Fifteen Escherichia strains were isolated onto sorbitol MacConkey agar. They were characterized as facultative anaerobic bacilli that ferment lactose and mannitol, indole positive, reduce nitrate and oxidase negative. According to these characteristics as well as their metabolic activities, they were identified as E. coli. E. coli O157:H7 antiserum was used to identify $E$. coli O157:H7 from other strains. E. coli isolated strains were coded as : 4, 7, 11, 12, 13, 15, 16, 18, 21, 22, 23, 26, 28, 29 and 30. E. coli $\mathrm{O} 157: \mathrm{H} 7$ isolated strains were coded as: 4.11.13.16.22.28.30

In group 2, Gram-positive, anaerobic, nonspore forming cocci, one bacterial strain (26) was isolated and characterized as Gram-positive, obligatory anaerobic, non spore forming, non motile small cocci that arranged in pairs and in short chains. It produced acid from cellobiose, fructose, lactose, and mannose. It was suggestive to be $S$. parvulus.

In group 3, Gram-positive anaerobic spore forming bacilli, two bacterial isolates $(2,8)$ were Gram-positive, strictly anaerobic, spore-forming bacilli. The spores were terminal to subterminal, swollen and showed complete haemolysis. These two strains were identified as $\mathrm{Cl}$. Baratii (2) and Cl. botulinum (8) according to Holdeman el al., 1977. 
Table (3): Anaeerobic bacterial isolates.

\begin{tabular}{|c|c|c|}
\hline Sample No. & Bacterial isolate cod No. & Bacterial isolate identity \\
\hline A1 & 2 & Cl. baratii \\
\hline C3 & 8 & Cl. botulinum \\
\hline B10 & 25 & S. parvulus \\
\hline
\end{tabular}

Table (4): E. coli and Salmonella isolates.

\begin{tabular}{|c|c|c|c|c|c|}
\hline $\begin{array}{c}\text { Sample } \\
\text { No. }\end{array}$ & $\begin{array}{l}\text { Bacterial } \\
\text { isolates } \\
\text { cod No. }\end{array}$ & Bacterial strain & Sample No. & $\begin{array}{l}\text { Bacterial } \\
\text { isolates } \\
\text { cod No. }\end{array}$ & Bacterial strain \\
\hline A1 & 1 & S. typhi & C7 & 17 & S. arizonae \\
\hline B1 & 3 & S. arizonae & A8 & 18 & E. coli \\
\hline $\mathrm{C} 2$ & 4 & E. coli $\mathrm{O} 157: \mathrm{H} 7$ & C8 & 19 & S. infantis \\
\hline B2 & 5 & S. typhi & A9 & 20 & S. typhi \\
\hline B3 & 6 & S. infantis & B9 & 21 & E. coli \\
\hline C3 & 7 & E. coli & C9 & 22 & E. coli O $157: \mathrm{H} 7$ \\
\hline C4 & 9 & S. arizonae & A10 & 23 & E. coli \\
\hline A5 & 10 & $S$ typhi & B10 & 24 & S. typhi \\
\hline B5 & 11 & E. coli $\mathrm{O} 157: \mathrm{H} 7$ & C10 & 26 & E. coli \\
\hline C5 & 12 & E. coli & A11 & 27 & S. typhi \\
\hline A6 & 13 & E. coli $\mathrm{O} 157: \mathrm{H} 7$ & B11 & 28 & E. coli $\mathrm{O} 157: \mathrm{H} 7$ \\
\hline B6 & 14 & S. arizonae & B12 & 29 & E. coli \\
\hline C6 & 15 & E. coli & $\mathrm{C} 12$ & 30 & E. coli $\mathrm{O} 157: \mathrm{H} 7$ \\
\hline B7 & 16 & E. coli O 157:H7 & & & \\
\hline
\end{tabular}

\section{Discussion}

Food borne illness is a major health problem that encounters not only the risk patient but also physicians, epidemiologists, food inspectors and laboratory microbiologists. Food borne infections constitute risk on the customer life, and cause economic losses due to increased hospitalization and therapy costs. Meat is a good medium for aerobic, facultative anaerobic and anaerobic bacteria. Meat products' ingredients increase the microbial contamination of final product. Increased artificial and chemical ingredients, use of old production lines and procedures, unhealthy workers as well as bad factories hygiene have increase the risk of food products contamination.

Mortadella is a desirable product; hence its contamination is considered a potential source of human infection.

The present study concentrates mainly on the possibility of presence of viable bacteria counts and certain pathogenic bacteria that may contaminate the Mortadella product in three Palestinian factories. Mean viable bacterial counts were greatly variable through this study. A remarkable variation may be due to the variation in the sampling time (June, 1999-May, 2000). The lowest viable bacterial count recorded was $1 \times 10^{3} \mathrm{CFU} / \mathrm{g}$ in sample A5 and the highest viable bacterial count recorded in sample B5 to be $3 \times 10^{7} \mathrm{CFU} / \mathrm{g}$. The recorded viable bacterial counts may be due to improper ventilating system, using improper standard constituents as well as improper hygienic measures. According to the results of total bacterial count, 18 of the investigated Mortadella samples were acceptable and 18 samples were unacceptable for human consumption.

All the isolated bacterial strains were purified and identified to the species level. Four genera were obtained: Salmonella, Escherichia, Clostridium as well as the anaerobic Streptococcus. Isolates belonging to the genus Salmonella represented $40 \%$ of the total bacterial isolates. They comprised three different species viz $S$. typhi (6 strains), S. arizonae (4 strains), and $S$. infantis (2 strains). Isolates belonging to the genus Escherichia represented $50 \%$ of the total bacterial isolates and were identified as one species Escherichia coli, while 7 stains were identified as E. coli $0157: \mathrm{H} 7$ (23.3\% of the total bacterial isolates). One anaerobic isolate was identified as Streptococcus parvulus that represented $3.3 \%$ of the total bacterial isolates. Clostridium spp. represented $6.7 \%$ of the total bacterial isolates and were identified into 2 species vis Clostridium baratii (one strain) and Clostridium botulinum (one strain). Three samples A1, C3 and B10 were mixture of two pathogenic bacterial strains.

The importance of these bacterial strains lies on the fact that they are responsible of exerting human pathogencity. Salmonellae cause enteritis, systemic infection and enteric fever 
(Miller and Pegues, 2000). Salmonella spp. produce endotoxins complex macromolecules containing lipoplysaccharide. E. coli is an important indicator of fecal contamination, however, E. coli causes different human infections. E. coli $\mathrm{O} 157: \mathrm{H} 7$ is recognized as the primary cause of haemorrahgic diarrhea and haemolytic uremic syndrome, producing two toxins (Stephen et al., 1994). S. parvulus is considered as a potential food contamination pathogens, however, $S$. parvulus is one of the respiratory tract microbial flora. Clostridium species are highly dangerous causative agents of gangrene and botulism. They produce a wide variety of toxins that are hemolytic, cardiotoxic, necrotizing, collagenolytic and proteolytic. Lecithinase is rapidly lethal $\alpha$ - toxin that caused lysis of all kinds of cell membranes and disruption of mitochondria (Shapiro, 1998 and Allen et. al., 2003).

Results obtained the present study necessitate the use of HACCP concept on meat processing factories. All factories should ensure properly ventilated production sites, sterile instruments and factory production stuff wearing clean sterile over wear etc. Strict regulations on meat processing factories should be adopted to minimize or obviate the risk of food infection or intoxication.

\section{References}

Abdel-Hady, M. H. (2000): Campylobacter regional training course on Microbiology of food of animal origin $3^{\text {rd }}$ Sept. $-5^{\text {th }}$ October. Fac. Vet. Med. Cairo Univ., Egypt

Abdul-Raouf, U. M.; Beuchat, L. R. and Ammar, M. S. (1993): Survival and growth of E. coli $\mathrm{O} 157: \mathrm{H} 7$ on salad vegetables. App. Env. Microbiol., 1999-2006

Abdul-Raouf, U. M. and Ammar, M. S. (1995): Isolation and identification of E. coli O157:H7 from Egyptian foods. $1^{\text {st }}$ Int. Sci. Conf. Fac. Sci., Al-Azhar Univ., Cairo, Egypt.

Abdul-Raouf, U. M.; Beuchat, L. R.; Zhao, T. and Ammar, M. S. (1994): Growth and Vero toxin I production by $E$. coli $\mathrm{O} 157: \mathrm{H} 7$ in ground roasted beef. Int. J. Food Microbiol., 23: 79-88.

Allen, S. D. S.; Emery, C. L. and Lyerly, D. M. (2003): Clostridium in: Manual of Clinical Microbiology, $8^{\text {th }}$ ed. Murray P.R. et al (ed.). A.S.M. Press.

American Society For Microbiology (1981): Manual of Methods for General Bacteriology . Washington,DC 20006. Angelotti, R.; Elizabeth, W.; Foter, M. J. and Lewis, K. H. (1959): Time-temperature effects on Salmonella and staphylococci in foods. U.S. Dept. of health report A. Taft Sait . Eng. Cent. Tech. Rep. F 59-2.

Ayres, J. C. (1955): Microbiological implications in the handling Slaughtering and dressing of meat animals. Adv. Food Res., 6: 110-161.

Barritt, M. (1936): The identification of the Voges Proskauer reaction by the addition of $\alpha$-naphthol. J. Pathol. Bact., 42: 441-454.
Board, R. G. and Holding, A. J. (1960): The utilization of glucose by aerobic Gram-negative bacteria, J. Appl. Bact., 23: $11-12$.

Botton, D. J.; Byrne, C. and Sheridan, J. J. (1998): Survival characteristics of E. coli O157:H7 and transfer from the contaminated hide to the carcass during slaughter. Proc. $44^{\text {th }}$ Int. Cong. Meat Sci. Tech., , Barcelona, Spain,pp350351.

Chapman, G. S. (1952): A simple method for making multiple tests on a microorganism. J. Bacteriol., 63: 147.

Conklin, M.E. (1934): Mercurochrome as a bacteriological stain. J. Bacteriol., $27: 30$.

Edward, P.R. and Ewing, W.H. (1972): Identification of Enterobacteriaceae Minneoplis, Burges. Publ. Co. Atlanta, USA.

Ewing, W. H. and Davis B. R. (1970) : Media and tests for differentiation of Enterobacteriaceae, Atlanta , U.S. Dept. of Health Education and Welfare, Center for Disease Control .

Hali, H. E. and Angelotti R. (1965): Clostridium perfringens in meat and meat product Appl. Microbiol., 13: 352-357.

Hazelger, C. W. (1995): Studies on Campylobacter jejuni. Appl. Env. Microbiol., 27: 2713-2719

Huker,G.H. (1927) : Further studies on the methods of Gram-staining . N.Y. State Agr. Expt. Sta. Tech.Bull, 128. ICMSF (1978): International Committee on Microbiological Specification on Foods: Microorganisms in Foods: their significance and Method of enumeration $.2^{\text {nd }}$ ed. Vol. 1.Univ. Toronto , Presses, Toronto and Buffalo Canada

James, M. J. (1978) : Modern Food Microbiology $2^{\text {nd }}$ ed. ,Wayne State University D. Van Nostrand Co. New York, Cincinnati, Toronto, London, Melbourne.

Joklik, W. and Amos, C. (1980): Yersinia. Zencser Microbiol., $17^{\text {th }}$ ed., 768 .

Kovacs, N. (1956): Identification of Pesudomomas Pyocyanea by the oxides reaction. Nature, 178: 703.

Krieg, N. R.; Holt, J. G.; Murray R. G. E.; Brenner, D. J.; Bryant M. P.; Moulder J. W.; Pfenning, N.; Sneath, P. H.; Staley J. T.; Lapage, S. P.; Niven J. V. and Charles F. (1986): Bergey's Manual of Determinative Bacteriology, $9^{\text {th }}$ ed. Vol.2, Williams and Wilkens Co. Baltimore London, Los Angeles, Sydney.

Kun, E. and Abood L. G. (1949): Biochemical properties of succinate, oxidase from Salmonella aertryke. J. Biol. Chem., 180: 812-823.

Leifson , E. (1952): An improved reagent for acetyl methyl carbinol test. J. Bact. 23: 353-354.

Lewis, A. and Chattopadhyuo, P. B. (1986): Faecal carriage rate of Yersinia enterocolitica . J. Hyg. Comb., 97 : 281-287.

Miller, S. I. and Pegues, D. A. (2000): Salmonella spp. in: Mandell, Douglas and Bennett's Principles and Practice of Infectious Diseases, $5^{\text {th }}$ ed. Mandell, G.L., Bennett J.E. and Dolin , R. (eds) . Churchill Livingstone.

Moller, V. (1954): Diagnostic use of the Brann KCN test within the Enterobateriaceae . Acta. Path. Microbiol. Scand., 34: 115-126.

Moller, V. 1955): Simplified test for some amino acids decarboxylases and for arginine dihydrolase system. Acta. Path. Microbiol. $2^{\text {nd }}$ ed. 36: 158-172.

Mossel, D. A. A. (1962): Significance of Microorganisms in foods, In J.C. Ayers A. A. Kraft, H. E. Snyder, and H. W. Walker (eds.) Chemical and biological hazards in food. The Iowa state University press, Ames, Iowa. pp. 157-201. NIH (1946): National Institute of Health. Circular 1946: Culture Media for the sterility test. Barker publication Ltd. 
Patricia, C. K.; Lapage, S.P. and Thelate K. J. (1966): Biochemical Identification Method, for Microbiologists, edited by Gibbs B.M. and Skinner F.A. Academic press.

Robert, L. B. and Sharon, G. E. 1999): pH-dependent stationary-phase acid resistance response of EHEC in the presence of various acid-diluents, J. Food Prot., 62 (3): 211 -218 .

Scott, W. J. (1957): Water relations of food spoilage microorganisms. Adv. Food Res., 7:83-127.

Shapiro, R. L. (1998): Botulism in the U.S. a clinical and epidemiologic review. Ann. Intern. Med., 129-221.

Shaw, C. and Clark, P.H. (1955): Biochemical classification of Proteus and Providencia cultures. J. Gen. Microbiol. 13: $155-161$.

Sheroff, B. J.; Slocum, G. G. and Decker, W. M. (1964): Status of botulism in the United States . Pub. Health Rep., 79: 871-878.
Sinell, H. J. and Baumgar, J. (1967): Selektivnahrboden mit Eigelb zur Isolierung Von Pathogenen Staphylokokin aus , Lebnsmittenln-Zbl-Bakt., I.org., 204: 248-264.

Stainer, R. Y. and Palleroni N. J.(1966): The aerobic Pseudomonas A taxonomic study . J. Gen. Microbiol., 43: 159-271.

Stephen,J.; Wallis, T. S. and Starkey W. G. (1994): Salmonellosis: in retrospect and prospect. In: Toxins and Diarrhea Disease. Ciba Found. Symp. 112. Pitman Press, London. 175.

Stern, N. J. (1982): Methods for recovery of Campylobacter jejuni from food. J. food Prot. , 45 (14): 1332-1337. Stilps, M. E. (1981): use of Baird Parcker's medium to enumerate Staphylococcus aureus in meats. J. Food Prot., 44: 583 .

Sutter, V. L.; Vargo V. L. and Finegold S. M. (1975): Wadsworth Anaerobic Bacteriology Manual, $2^{\text {nd }}$ ed., Los Angeles, the Reagents of the University of California. 